J. Product. \& Dev., 14(3): 545-570(2009)

\title{
EFFECT OF PLANTING DISTANCES AND SOME MICRO- ELEMENTS ON THE GROWTH,YIELD AND SOME CHEMICAL CONSTITUENTS OF ROSELLE (Hibiscus sabdariffa, L.) PLANT.
}

\author{
M. S. Hanafy \\ Ornamental Hort. Department,. Faculty of Agriculture, Cairo University, \\ Egypt.
}

\section{ABSTRACT}

This experiment was carried out at the Agriculture Experimental Station, Faculty of Agriculture, Cairo University, Giza in two successive seasons 2006 and 2007. The aim of this research was to study the effect of planting distances between the plants and foliar spray with some microelements on the growth, yield and some chemical constituents of roselle plant.

The plants were sprayed with Zero (control), 90 and 180 ppm. $(\mathrm{Fe}+$ $M n+Z n$ together). The planting distances between the plants in this experiment were 40, 60 or $80 \mathrm{~cm}$. There was constant distance between the rows (60 cm.). The obtained results can be summarized as follows:

The foliar spray with micro-elements at the rates of 90 or $180 \mathrm{ppm}$. increased all the recorded characters of the growth, yield and chemical constituents as compared with the control treatment. The highest values of number of branches/plant, stem diameter, number of fruits/plant, yield of fresh fruits/plant, yield of fresh and dry sepals/plant and total soluble solids\% were obtained with foliar spray by micro- elements at 90 ppm.

Also, the highest plant height, number of leaves/plant, chlorophyll A, $B$, carotenoids, total carbohydrates \%, anthocyanin content, $\mathrm{pH}$ value, $\mathrm{Fe}$, $\mathrm{Mn}$ and $\mathrm{Zn}$ contents were obtained with foliar spray with micro-elements at 180 ppm. As well as the greatest yield of dry seeds/plant was obtained with foliar spray by micro- elements at 90 ppm. in the first season and $180 \mathrm{ppm}$. in the second season. The lowest values of all recorded parameters of growth, yield and chemical constituents were obtained with the untreated plants with micro-elements (control).

The highest values of all recorded characters of the growth, yield and chemical constituents were obtained with the wider space between the plants $(80 \mathrm{~cm}$.) followed by medium space $(60 \mathrm{~cm})$ then narrow space $(40$ cm.).

On the other hand, the opposite response occurred with plant height which the tallest plants were produced from the narrow distance between the plants $(40 \mathrm{~cm}$.). 
The interaction between micro- elements at 90 or 180 ppm. and different planting spaces increased all the recorded parameters of the growth, yield and chemical constituents as compared with the interaction between micro-elements at zero (control) and all different planting distances in most cases.

Key words: Planting distances, micro-elements, iron, manganese, zinc, growth, yield, chemical constituents, roselle plant.

\section{INTRODUCTION}

Roselle plant (Hibiscus sabdariffa, L.) belongs to family Malvaceae which is widely cultivated in tropical and subtropical regions for its calyxes, fibers and seeds for medical and industrial uses.

Many investigators pointed out to the importance of planting distances and micro-elements in increasing growth, yield and some chemical constituents of many plants. The wider planting distances led to an increase in growth and yield in many plants, this result reported by many investigators such as El-Gendy et al. (2001) on Ocimum basilicum cv. Grande Verde, Ali (2008) on Origanum syriacum, L. and Hanafy et al. (2009 a) on Rosmarinus officinalis, L. Also the wider planting spaces led to an increase in some chemical constituents of many plants, this result stated by many researches such as Ibrahem (2000) on total carbohydrates content in Ammi visnaga, ElSherbeny et al. (2005) on some chemical constituents in Sideritis montana, Ali (2008) on carbohydrates content in Origanum syriacum and Hanafy et al. (2009 a) on chlorophyll A, B, carotenoids and total carbohydrates content in Rosmarinus officinalis.

As well as the foliar spray with some micro-elements such as iron, zinc and manganese on some plants led to an increase in growth and yield, this the result reported by many investigators, Shoala (2000) on Lavandula multifida treated with Zn, El-Shobaky and Abd El-Mageed (2001) on pea plant treated with Fe, Zn or Mn, El-Sawi and Mohamed (2002) on cumin treated with $\mathrm{Zn}$ and Mn and Hanafy et al. (2009 b) on Rosmarinus officinalis treated with zinc.

Also, the foliar spray with some micro-elements such as Fe, Mn or $\mathrm{Zn}$ increased some chemical constituents in some plants such as chlorophyll A, $\mathrm{B}$, carotenoids, total carbohydrates, $\mathrm{Fe}, \mathrm{Mn}$ and $\mathrm{Zn}$, anthocyanin, $\mathrm{pH}$ values and total soluble solids contents. This result reported by many researchers, Shoala (2000) on chlorophyll B and carotenoids contents in Lavandula multifida treated with zinc, El-Sawi and Mohamed (2002) on chemical composition of cumin plants which treated with $\mathrm{Zn}$ and Mn and Hanafy et al. 
(2009 b) on chlorophyll A, B, carotenoids and zinc contents in Rosmarinus officinalis treated with zinc. Thus this experiment aimed to study the response of Hibiscus sabdariffa plant to different planting distances and some microelements to improve its growth, yield and some chemical constituents.

\section{MATERIALS AND METHODS}

This experiment was carried out at the Agriculture Experimental Station, Faculty of Agriculture, Cairo University, Giza in two successive seasons 2006 and 2007.

Roselle seeds were sown in rows on $26^{\text {th }}$ May 2006 and 2007. The space between rows $60 \mathrm{~cm}$. and the distances between hills in rows were 40 , 60 or $80 \mathrm{~cm}$.

Five seeds were sown in a hill, one month after the sowing date, the seedlings were thinned to one plant/hill. The analysis of the soil which were used can be seen in the following Table A:

Table A. Physical and chemical analysis of the soil

\begin{tabular}{|c|c|c|c|c|c|c|c|c|c|c|c|c|c|c|}
\hline \multirow{2}{*}{$\begin{array}{c}\text { Coars } \\
\text { sand } \\
\%\end{array}$} & \multirow{2}{*}{$\begin{array}{c}\text { Fine } \\
\text { sand } \\
\%\end{array}$} & \multirow{2}{*}{$\begin{array}{c}\text { Silt } \\
\%\end{array}$} & \multirow{2}{*}{$\begin{array}{c}\text { Clay } \\
\%\end{array}$} & \multirow{2}{*}{$\begin{array}{l}\text { Soil } \\
\text { type }\end{array}$} & \multirow{2}{*}{\multicolumn{2}{|c|}{$\begin{array}{cc} & \text { Organic } \\
\text { pH } & \begin{array}{c}\text { matter } \\
\%\end{array} \\
\end{array}$}} & \multirow[b]{2}{*}{ SP } & \multirow{2}{*}{$\begin{array}{c}\text { E.C. } \\
\text { mmos } / \mathrm{cm} . \\
\text { at } 20^{\circ} \mathrm{C} \\
\end{array}$} & \multicolumn{6}{|c|}{ Concentration ppm. } \\
\hline & & & & & & & & & $\mathbf{N}$ & $\mathbf{P}$ & $\mathbf{K}$ & $\mathbf{F e}$ & Zn & Mn \\
\hline 13.5 & 53.3 & 8.6 & 24.3 & $\begin{array}{l}\text { Sandy } \\
\text { clay } \\
\text { loam }\end{array}$ & 7.5 & 2.18 & 36 & 1.12 & 51.7 & 12.15 & 310.12 & 50.01 & 30.13 & $25 . .18$ \\
\hline
\end{tabular}

The plants were sprayed with some micro-elements $(\mathrm{Fe}+\mathrm{Mn}+\mathrm{Zn}$ together) at the rates of zero (control), 90 or $180 \mathrm{ppm}$. The control plants were sprayed with distilled water. The chelated EDTA forms of $\mathrm{Fe}(6 \%), \mathrm{Mn}$ $(13 \%)$ and $\mathrm{Zn}(14 \%)$ produced by ABM chemicals, Ltd, UK. The volume of the sprayed solution of $\mathrm{Fe}, \mathrm{Mn}$ and $\mathrm{Zn}$ was maintained just to completely covered the plant foliage till drip. The plants were sprayed twice; the first spray was after 45 days from planting, while the second spray was carried out after 30 days from the first one.

All the plants of the experiment received $5 \mathrm{~g}$. NPK at the ratio of 100:100:100 at 30 days from planting as first dose, while the second dose (5 g. NPK) was added after 30 days from the first one. At harvest time in November 2006 and 2007, the following data were recorded:

1- Plant height $(\mathrm{cm}$.).

2- Number of leaves and branches /plant.

3- Stem diameter $(\mathrm{cm}$.).

4- Number of fruits/plant.

5- Yield of fresh fruits and sepals /plant (g.). 
6- Yield of dry sepals and seeds /plant (g.).

7- Chlorophylls A, B and carotenoids contents (mg/g. F.W.).

8- Total carbohydrates \%.

9- Anthocyanin content (mg/g. D.W.).

10- $\mathrm{pH}$ values.

11- T.S.S. \%.

12- Fe, Mn and $\mathrm{Zn}$ contents (ppm.).

- Main stem diameter was taken at fifth node above the soil surface.

- Chlorophylls A, B and carotenoids contents in the roselle fresh leaves were determined according to Saric et al. (1976).

- Total carbohydrates was determined in dry leaves according to Herbert et al. (1971).

- Anthocyanin content was determined in dry sepals according to the methods described by Fahmy (1970).

- $\mathrm{pH}$ values in the beverage of sepals were determined by using a $\mathrm{pH}$ meter according to Diab (1968).

- Total soluble solids \% was determined by using 15 fruits/treatment for obtaining juice from calyces and epicalyces then T.S.S. \% determined in juice by a hand refractometer.

- $\mathrm{Fe}, \mathrm{Mn}$ and $\mathrm{Zn}$ contents in the dried samples of leaves were determined by using Atomic Absorption/ Flame photometer.

The statistical analysis of the experiment was split plot in randomized complete blocks design. Data were statistically analyzed using MSTAT-C software package according to Freed et al. (1989) and the data were subjected to analysis of variance according to Steel et al. (1997).

\section{RESULTS AND DISCUSSION}

\section{1- Plant height (cm.):}

Data shown in Table (1) indicated that micro-element $(\mathrm{Fe}+\mathrm{Mn}+\mathrm{Zn}$ together) at 90 or $180 \mathrm{ppm}$. had a significant effect on increasing plant height as compared with control treatment. The micro-elements at 90 or $180 \mathrm{ppm}$. increased plant height as compared with the control treatment. The plant height increased as the concentration of micro-elements increased in the two seasons. In the first season, the tallest plants $(164.34$ and $154.19 \mathrm{~cm}$.) were produced with 180 and $90 \mathrm{ppm}$. treatments, respectively, while the shortest plants $(137.38 \mathrm{~cm}$.) were produced from the control plants. The same trend was found in the second season, with significant differences between the control and the other micro-elements treatments. 
Table 1. Plant height (cm.) of Hibiscus sabdariffa $\mathbf{L}$. plant as affected by planting distances and some micro-elements, in 2006 and 2007 seasons.

\begin{tabular}{|c|c|c|c|c|c|c|c|c|}
\hline \multirow{3}{*}{$\begin{array}{l}\text { Micro-elements } \\
\text { concentrations } \\
(\mathrm{Fe}+\mathrm{Mn}+\mathrm{Zn}) \mathrm{ppm}\end{array}$} & \multicolumn{8}{|c|}{ Planting distances $(\mathbf{c m})}$. \\
\hline & 40 & 60 & 80 & Mean & 40 & 60 & 80 & Mean \\
\hline & \multicolumn{4}{|c|}{$(2006)$} & \multicolumn{4}{|c|}{$(2007)$} \\
\hline Zero (control) & 151.33 & 130.33 & 130.49 & $\mathbf{1 3 7 . 3 8}$ & 172.22 & 145.78 & 164.45 & 160.82 \\
\hline 90 & 167.56 & 139.56 & 155.44 & 154.19 & 182.89 & 203.66 & 182.22 & .59 \\
\hline 180 & 192.45 & 166.00 & 134.56 & 164.34 & 202.33 & 198.67 & 195.78 & 198.93 \\
\hline Mean & $\mathbf{1 7 0 . 4 5}$ & 145.30 & 140.16 & & 185.81 & 182.70 & 180.82 & \\
\hline L.S.D at 0.05 for: & $\begin{array}{l}\text { lanting } \\
\text { Micro-e } \\
\text { nteract }\end{array}$ & $\begin{array}{l}\text { distanc } \\
\text { ements } \\
\text { on }\end{array}$ & $\begin{array}{l}= \\
= \\
=\end{array}$ & $\begin{array}{c}9.96 \\
11.29 \\
19.55\end{array}$ & & & & $\begin{array}{l}=\text { N.S. } \\
=13.54 \\
=23.46\end{array}$ \\
\hline
\end{tabular}

Regarding planting distances, it was clear that, in the first season, planting space at $40 \mathrm{~cm}$. had a significant effect on increasing plant height as compared with planting spaces at 60 or $80 \mathrm{~cm}$. planting distances at 40,60 or $80 \mathrm{~cm}$. gave plant height $(170.45,145.30$ and $140.16 \mathrm{~cm}$.) respectively. Similar trend was observed in the second season.

The interaction between micro-elements and planting distances had a significant effect on plant height, it was evidence that in the first season the tallest plants $(192.45 \mathrm{~cm}$.) were resulted in planting space at $40 \mathrm{~cm}$. and foliar spray with micro-elements at 180 ppm., while in the second season the tallest plants $(203.66 \mathrm{~cm}$.) were obtained with planting space at $60 \mathrm{~cm}$. and application of micro-elements at $90 \mathrm{ppm}$.

These results were in agreement with those obtained by El-Sawi and Mohamed (2002) found that application of micronutrients had significant positive effects in most cases on growth measurements of cumin plant. Hanafy et al. (2009 a) on Rosmarinus officinalis, stated that increasing the distance between the plants from 20 to $80 \mathrm{~cm}$. decreased steadily plant height.

\section{2- Number of leaves/plant at time of the harvest:}

As shown in Table 2, it was clear that the number of leaves/plant increased as the micro-elements concentrations increased. In the first season, the numbers of leaves/plant $(9.73,11.13$ and 24.67) were obtained with micro-elements at zero, 90 or $180 \mathrm{ppm}$. respectively. While, in the second season the numbers of leaves/plant $(14.89,44.70$ and 48.03) were resulted in micro-elements at zero, 90 or $180 \mathrm{ppm}$. respectively. Regarding the effect of planting distances on number of leaves/plant it was clear that the number of leaves/plant increased as the distance between the plants increased. In the first Table 2. Number of leaves/plant of Hibiscus sabdariffa, L. plant as 
affected by planting distances and some micro-elements, in 2006 and 2007 seasons.

\begin{tabular}{|c|c|c|c|c|c|c|c|c|}
\hline \multirow{2}{*}{$\begin{array}{l}\text { Micro-elements } \\
\text { concentrations } \\
(\mathrm{Fe}+\mathrm{Mn}+\mathrm{Zn}) \mathrm{ppm} .\end{array}$} & \multicolumn{8}{|c|}{ Planting distances (cm.) } \\
\hline & 40 & 60 & 80 & Mean & 40 & 60 & 80 & Mean \\
\hline & \multicolumn{4}{|c|}{$(2006)$} & \multicolumn{4}{|c|}{ (2007) } \\
\hline Zero (control) & 8.67 & 9.37 & 11.15 & 9.73 & 13.22 & 9.78 & 21.67 & 14.89 \\
\hline 90 & 9.67 & 10.56 & 13.17 & 11.13 & 39.55 & 41.22 & 53.33 & 44.70 \\
\hline 180 & 21.89 & 26.33 & 25.78 & 24.67 & 44.66 & 51.11 & 48.33 & 48.03 \\
\hline Mean & 13.41 & 15.42 & 16.70 & & 32.48 & 34.04 & 41.11 & \\
\hline \multicolumn{3}{|c|}{ L.S.D at 0.05 for: Planting distances } & & $=1.80$ & & & & $=$ N.S. \\
\hline \multicolumn{3}{|c|}{ : Micro-elements } & & $=3.11$ & & & & $=6.06$ \\
\hline \multicolumn{3}{|c|}{ : Interaction } & & $=5.38$ & & & & $=10.49$ \\
\hline
\end{tabular}

season, the numbers of leaves/ plant (13.41, 15.42 and 16.70) were obtained with planting spaces at 40,60 or $80 \mathrm{~cm}$., respectively, with significant differences between planting space at $40 \mathrm{~cm}$. and other planting distances.

A similar trend was observed in the second season. The interaction between planting distances and micro-elements treatments had a significant effect on increasing number of leaves/plant. In the first season the highest numbers of leaves (26.33 and 25.78) were obtained with interaction between foliar spray by micro-elements at $180 \mathrm{ppm}$. and planting distances at 60 and 80 cm., respectively.

The same trend was found in the second season. Generally number of leaves/plant increased as the planting distances or micro-elements increased and the interaction between micro-elements at 90 or $180 \mathrm{ppm}$. and different planting distances caused a clear effect on increasing number of leaves/plant in the two seasons. These results were in agreement with those obtained by El-Sawi and Mohamed (2002).

\section{3- Number of branches/plant:}

As shown in Table 3, the number of branches/plant increased significantly with micro-elements at 90 or $180 \mathrm{ppm}$. as compared with the control treatment in the two seasons. In the first season, the number of branches/ plant $(13.55,18.81$ and 16.74) were obtained with micro-elements at zero, 90 or 180 ppm., respectively, while in the second season the number of branches/ plant (16.71, 27.67 and 25.45) were resulted in micro-elements at zero, 90 or 180 ppm., respectively. Concerning to planting distances, it was clear that, the number of branches/ plant increased as the distances between the plants increased.

In the first season, the number of branches/plant (14.14, 16.52 and 18.44) were produced with planting spaces at 40,60 or $80 \mathrm{~cm}$., respectively, Table 3. Number of branches/ plant of Hibiscus sabdariffa, L. plant as 
affected by planting distances and some micro-elements, in 2006 and 2007 seasons.

\begin{tabular}{|c|c|c|c|c|c|c|c|c|}
\hline \multirow{2}{*}{$\begin{array}{l}\text { Micro-elements } \\
\text { concentrations } \\
(\mathrm{Fe}+\mathrm{Mn}+\mathrm{Zn}) \text { ppm. }\end{array}$} & \multicolumn{8}{|c|}{ Planting distances $(\mathbf{c m})}$. \\
\hline & 40 & 60 & 80 & Mean & 40 & 60 & 80 & Mean \\
\hline & \multicolumn{4}{|c|}{ (2006) } & \multicolumn{4}{|c|}{ (2007) } \\
\hline Zero (control) & 12.87 & 12.45 & 15.33 & 13.55 & 11.67 & 14.67 & 23.78 & 16.71 \\
\hline 90 & 13.44 & 20.22 & 22.78 & 18.81 & 29.45 & 25.67 & 27.89 & 27.67 \\
\hline 180 & 16.11 & 16.89 & 17.22 & 16.74 & 22.89 & 25.89 & 27.56 & 25.45 \\
\hline Mean & 14.14 & 16.52 & 18.44 & & 21.34 & 22.08 & 26.41 & \\
\hline \multicolumn{4}{|c|}{ L.S.D at 0.05 for: Planting distances } & $\begin{array}{l}=2.1 \\
=1.7 \\
=3.0\end{array}$ & & & & $\begin{array}{l}=\text { N.S. } \\
=1.89 \\
=3.27\end{array}$ \\
\hline
\end{tabular}

while in the second season, the numbers of branches/plant $(21.34,22.08$ and 26.41) were obtained with planting spaces at 40,60 or $80 \mathrm{~cm}$. respectively.

The interaction between micro-elements and different planting distances had a clear effect on increasing number of branches/plant as compared with the interaction between micro-elements at zero and different planting spaces in the two seasons in most cases. In the first season, the highest number of branches/plant (22.78) was obtained from the interaction between microelements at $90 \mathrm{ppm}$. and planting space at $80 \mathrm{~cm}$., while in the second season, the greatest number of branches/ plant (29.45) was produced with the interaction between micro-elements at $90 \mathrm{ppm}$. and planting distance at $40 \mathrm{~cm}$. These findings were in line with those of El-Gendy et al. (2001) on Ocimum basilicum $\mathrm{cv}$. Grande Verde, stated that widening plant spacing significantly increased the number of branches.

\section{4- Stem diameter (cm.):}

The data exhibited in Table (4) pointed out that stem diameter increased significantly with micro-elements at 90 or $180 \mathrm{ppm}$. as compared with the untreated plants (control) in the two seasons. In the first season the stem diameter $(1.092,1.370$ and $1.273 \mathrm{~cm}$.) was obtained with micro-elements at zero, 90 or 180 ppm., respectively.

While in the second season, the stem diameter $(1.029,1.260$ and 1.226 $\mathrm{cm}$.) was obtained with micro-elements at zero, 90 or180 ppm. respectively. It was clear that in the two seasons, there are significant differences between the control treatment and micro-elements at 90 or $180 \mathrm{ppm}$. as general mean of the treatments of micro-elements.

Concerning to planting distances, it was clear that stem diameter increased as the planting spaces between the plants increased. In the first Table 4. Stem diameter (cm.) of Hibiscus sabdariffa, L. plant as affected 
by planting distances and some micro-elements, in 2006 and 2007 seasons.

\begin{tabular}{|c|c|c|c|c|c|c|c|c|}
\hline \multirow{2}{*}{$\begin{array}{l}\text { Micro-elements } \\
\text { concentrations } \\
(\mathrm{Fe}+\mathrm{Mn}+\mathrm{Zn}) \text { ppm. }\end{array}$} & \multicolumn{8}{|c|}{ Planting distances (cm.) } \\
\hline & 40 & 60 & 80 & Mean & 40 & 60 & 80 & Mean \\
\hline \multirow[b]{2}{*}{ Zero (control) } & \multicolumn{4}{|c|}{ (2006) } & \multicolumn{4}{|c|}{$(2007)$} \\
\hline & 1.133 & 1.033 & 1.110 & 1.092 & 0.953 & 1.033 & 1.100 & 1.029 \\
\hline 90 & 1.187 & 1.467 & 1.457 & $\mathbf{1 . 3 7 0}$ & 1.177 & 1.300 & 1.287 & 1.260 \\
\hline 180 & 1.300 & 1.287 & 1.233 & 1.273 & 1.177 & 1.233 & 1.267 & 1.226 \\
\hline Mean & 1.207 & 1.262 & 1.267 & & 1.102 & 1.189 & 1.218 & \\
\hline \multicolumn{3}{|c|}{ L.S.D at 0.05 for: Planting distances } & & $=\mathrm{N} . . \mathrm{S}$. & & & & $=0.110$ \\
\hline \multicolumn{3}{|c|}{ : Micro-elements } & & $=0.046$ & & & & $=0.080$ \\
\hline \multicolumn{3}{|c|}{ : Interaction } & & $=0.080$ & & & & $=0.138$ \\
\hline
\end{tabular}

season, stem diameters $(1.207,1.262$ and $1.267 \mathrm{~cm}$.) were resulted in planting distances at 40, 60 or $80 \mathrm{~cm}$., respectively, whereas in the second season, stem diameters $(1.102,1.189$ and $1.218 \mathrm{~cm}$.) were obtained with planting spaces at 40, 60 or $80 \mathrm{~cm}$., respectively.

The interaction between micro-elements at 90 or $180 \mathrm{ppm}$. and different planting spaces had a clear effect on increasing stem diameter as compared with the interaction between micro-elements at zero and different planting distances in the two seasons. The highest stem diameters (1.467 and $1.300 \mathrm{~cm}$.) were produced from the interaction between micro-elements at 90 ppm. and planting spaces at $60 \mathrm{~cm}$. in the first and second seasons, respectively.

These findings coincided with those of El-Sawi and Mohamed (2002) stated that application of micronutrients $(\mathrm{Zn}+\mathrm{Mn})$ had significant positive effects on growth measurements of cumin plant.

\section{5- Number of fruits/plant:}

As shown in Table 5, it can be observed that number of fruits/plant increased significantly with micro-elements $(\mathrm{Fe}+\mathrm{Mn}+\mathrm{Zn}$ together $)$ at 90 and $180 \mathrm{ppm}$. as compared with the control treatment in the two seasons.

In the first season, the numbers of fruits/plant $(19.44,27.15$ and 23.52) were obtained with micro-elements $(\mathrm{Fe}+\mathrm{Mn}+\mathrm{Zn}$ together) at zero (control), 90 and 180 ppm., respectively, while in the second season, the numbers of fruits/plant $(35.29,73.15$ and 69.19) were resulted in microelements at zero (control), 90 and 180 ppm., respectively. Regarding planting spaces, it was very clear that the number of fruits/plant increased as the distance between the plants increased.

Table 5. Number of fruits/plant of Hibiscus sabdariffa, L. plant as 
affected by planting distances and some micro-elements, in 2006 and 2007 seasons.

\begin{tabular}{|c|c|c|c|c|c|c|c|c|}
\hline \multirow{3}{*}{$\begin{array}{l}\text { Micro-elements } \\
\text { concentrations } \\
(\mathrm{Fe}+\mathrm{Mn}+\mathrm{Zn}) \text { ppm. }\end{array}$} & \multicolumn{8}{|c|}{ Planting distances (cm.) } \\
\hline & 40 & 60 & 80 & Mean & 40 & 60 & 80 & Mean \\
\hline & \multicolumn{4}{|c|}{2006} & \multicolumn{4}{|c|}{2007} \\
\hline Zero (control) & 15.65 & 19.67 & 23.00 & 19.44 & 23.33 & 31.11 & 51.44 & 35.29 \\
\hline 90 & 16.44 & 29.11 & 35.89 & 27.15 & 52.44 & 86.33 & 80.67 & 73.15 \\
\hline 180 & 22.55 & 21.33 & 26.67 & 23.52 & 64.33 & 67.56 & 75.67 & 69.19 \\
\hline Mean & 18.21 & 23.37 & 28.52 & & 46.70 & 61.67 & 69.26 & \\
\hline \multicolumn{3}{|c|}{ L.S.D at 0.05 for: Planting distances } & & $=5.98$ & & & & $=12.64$ \\
\hline \multicolumn{3}{|c|}{ : Micro-elements } & & $=3.72$ & & & & $=9.91$ \\
\hline \multicolumn{3}{|c|}{ : Interaction } & & $=6.44$ & & & & $=17.16$ \\
\hline
\end{tabular}

In the first season, the numbers of fruits/plant (18.21, 23.37 and 28.52 ) were produced with planting spaces at 40,60 or $80 \mathrm{~cm}$., respectively, whereas in the second season, the numbers of fruits/ plant $(46.70,61.67$ and 69.26) were obtained with planting distances at 40,60 or $80 \mathrm{~cm}$., respectively.

The interaction between micro-elements at 90 or $180 \mathrm{ppm}$. and different planting spaces had a clear effect on increasing number of fruits/plant as compared with the interaction between micro-elements at zero and different planting distances in the two seasons. In the first season, the highest number of fruits/plant (35.89) was obtained with the interaction between micro-elements at $90 \mathrm{ppm}$. and planting space at $80 \mathrm{~cm}$., whereas, in the second season, the highest number of fruits/plant (86.33) was produced with the interaction between micro-elements at $90 \mathrm{ppm}$. and planting space at $60 \mathrm{~cm}$. These results were in harmony with those obtained by many investigators such as Ibrahem (2000) on Ammi visnaga and Foeniculum vulgare, found that, increasing spacing between plants to $50 \mathrm{~cm}$. significantly increased number of umbels in both seasons.

\section{6- Yield of fresh fruits/plant (g.):}

Data in Table (6) showed that yield of fresh fruits/plant increased significantly by micro-elements at 90 or $180 \mathrm{ppm}$. as compared with the control treatment in the two seasons.

In the first season, the highest yield of fresh fruits/plant (160.26 g./ plant) was produced with micro-elements at $90 \mathrm{ppm}$, followed by $180 \mathrm{ppm}$. treatment which gave 123.11 g./ plant then decreased to 105.38 g./plant at zero micro-elements (control). In the second season the same trend was observed. Concerning to planting spaces, it was clear that yield of fresh fruits/ plant increased as the distance between the plants increased.

Table 6. Yield of fresh fruits/plant (g.) of Hibiscus sabdariffa, L. plant 
as affected by planting distances and some micro-elements, in 2006 and 2007 seasons.

\begin{tabular}{cccccccccc}
\hline $\begin{array}{l}\text { Micro-elements } \\
\text { concentrations } \\
\text { (Fe+Mn+Zn) ppm. }\end{array}$ & $\mathbf{4 0}$ & $\mathbf{6 0}$ & $\mathbf{8 0}$ & Mean & $\mathbf{4 0}$ & $\mathbf{6 0}$ & $\mathbf{8 0}$ & Mean \\
\cline { 2 - 9 } & \multicolumn{7}{c}{$\mathbf{2 0 0 6}$} & & \multicolumn{3}{c}{$\mathbf{2 0 0 7}$} \\
\cline { 2 - 9 } Zero (control) & 85.93 & 109.71 & 120.50 & $\mathbf{1 0 5 . 3 8}$ & 99.34 & 143.89 & 148.67 & $\mathbf{1 3 0 . 6 3}$ \\
$\mathbf{9 0}$ & 87.45 & 191.22 & 202.11 & $\mathbf{1 6 0 . 2 6}$ & 149.00 & 301.45 & 379.33 & $\mathbf{2 7 6 . 5 9}$ \\
$\mathbf{1 8 0}$ & 127.78 & 117.34 & 124.22 & $\mathbf{1 2 3 . 1 1}$ & 207.34 & 282.11 & 299.89 & $\mathbf{2 6 3 . 1 1}$ \\
\hline \multicolumn{1}{c}{ Mean } & $\mathbf{1 0 0 . 3 9}$ & $\mathbf{1 3 9 . 4 2}$ & $\mathbf{1 4 8 . 9 4}$ & & $\mathbf{1 5 1 . 8 9}$ & $\mathbf{2 4 2 . 4 8}$ & $\mathbf{2 7 5 . 9 6}$ \\
\hline L.S.D at 0.05 for: Planting distances & & $=25.28$ & & & & $=56.01$ \\
& : Micro-elements & & $=16.69$ & & & & $=25.62$ \\
& : Interaction & & $=28.90$ & & & & $=44.38$ \\
\hline
\end{tabular}

In the first season, yield of fresh fruits/ plant (100.39, 139.42 and 148.94 g./ plant) was obtained with planting spaces at 40,60 or $80 \mathrm{~cm}$., respectively while in the second season, yield of fresh fruits/plant (151.89, 242.48 and 275.96 g./ plant) was resulted in planting spaces at 40,60 or 80 $\mathrm{cm}$. between the plants, respectively. There are significant differences in yield of fresh fruits/ plant with planting distances at $40 \mathrm{~cm}$. and other distances in the both seasons. The interaction between micro-elements at 90 or $180 \mathrm{ppm}$. and different planting distances had a clear effect on increasing yield of fresh yield of fruits/ plant as compared with the interaction between micro-elements at zero and different planting spaces in the two seasons.

The highest yields of fresh fruits/plant (202.11 and $379.33 \mathrm{~g} . / \mathrm{plant})$ were obtained with the interaction between micro-elements $(\mathrm{Fe}+\mathrm{Mn}+\mathrm{Zn}$ together) at $90 \mathrm{ppm}$. and planting space at $80 \mathrm{~cm}$. in the first and second seasons, respectively.

These results were in agreement with those obtained by Ali (2008) on Origanum syriacum, L., stated that planting distance at $60 \mathrm{~cm}$. resulted in a significant increase in fresh weights/plant.

\section{7- Yield of fresh sepals/ plant (g.):}

Data shown in Table (7) revealed that the micro-elements at 90 and $180 \mathrm{ppm}$. had a clear effect on increasing yield of fresh sepals/plant as compared with the control in the two seasons.

In the first season, the highest yield of fresh sepals/ plant (54.33 g./ plant) was obtained with micro-elements at $90 \mathrm{ppm}$. followed by 42-18 g./ plant was obtained with micro-elements at $180 \mathrm{ppm}$., while the lowest yield of fresh sepals/plant (33.52 g./ plant) was produced from untreated plants with micro-elements (control). In the second season the yield of fresh sepals / plant was higher than in the first one. The yields of fresh Table 7. Yield of fresh sepals/ plant (g.) of Hibiscus sabdariffa, L. plant 
as affected by planting distances and some micro-elements, in 2006 and 2007 seasons.

\begin{tabular}{|c|c|c|c|c|c|c|c|c|}
\hline \multirow{2}{*}{$\begin{array}{l}\text { Micro-elements } \\
\text { concentrations } \\
(\mathrm{Fe}+\mathrm{Mn}+\mathrm{Zn}) \mathbf{p p m} .\end{array}$} & \multicolumn{8}{|c|}{ Planting distances (cm.) } \\
\hline & 40 & 60 & 80 & Mean & 40 & 60 & 80 & Mean \\
\hline & \multicolumn{4}{|c|}{2006} & \multicolumn{4}{|c|}{2007} \\
\hline Zero (control) & 24.08 & 38.81 & 37.67 & 33.52 & 58.00 & 77.33 & 57.78 & 64.37 \\
\hline 90 & 26.89 & 67.89 & 68.22 & 54.33 & 85.33 & 135.56 & 192.22 & 137.70 \\
\hline 180 & 42.44 & 41.55 & 42.56 & 42.18 & 117.78 & 120.11 & 142.55 & 126.81 \\
\hline Mean & 31.14 & 49.42 & 49.48 & & 87.04 & 111.00 & 130.85 & \\
\hline \multirow[t]{3}{*}{ L.S.D at 0.05 for } & \multicolumn{3}{|c|}{ : Planting distances } & \multicolumn{2}{|l|}{$=7.55$} & & & $=33.56$ \\
\hline & \multicolumn{3}{|c|}{ : Micro-elements } & \multicolumn{2}{|l|}{$=8.81$} & & & $=20.06$ \\
\hline & \multicolumn{3}{|c|}{ : Interaction } & \multicolumn{2}{|l|}{$=15.26$} & & & $=34.74$ \\
\hline
\end{tabular}

sepals/plant (64.37, 137.70 and 126.81 g./ plant) were produced with micro-elements at zero, 90 or $180 \mathrm{ppm}$., respectively thus, the same trend as in the first season was found.

Concerning to planting distances, it was clear that the yield of fresh sepals/ plant gradually increased as the distance between the plant increased in the two seasons.

In the first season, the yield of fresh sepals/ plant (31.14, 49.42 and 49.48 g./ plant) were resulted in planting spaces at 40,60 or $80 \mathrm{~cm}$., respectively, while in the second season, the yields of fresh sepals/ plant (87.04, 111.00 and $130.85 \mathrm{~g} . /$ plant) were obtained with planting distances at 40,60 or $80 \mathrm{~cm}$., respectively. Regarding interaction between micro-elements and planting spaces, it was clear that the interaction had a clear effect on increasing yield of fresh sepals/ plant.

The highest yields of fresh sepals/plant (68.22 and 192.22 g./ plant) were produced with the interaction between micro-elements at $90 \mathrm{ppm}$. and planting space at $80 \mathrm{~cm}$. in the first and second seasons, respectively.

It was very clear that, the interaction between micro-elements at 90 or $180 \mathrm{ppm}$. and planting distances increased yield of fresh sepals/plant as compared with the interaction between the micro-elements at zero ppm. and planting spaces.

\section{8- Yield of dry sepals/plant (g.):}

The data exhibited in Table (8) pointed out that, as yield of fresh sepals/plant. The micro-elements had a significant effect on yield of dry sepals/plant in the two seasons. In the first season, the highest yield of dry sepals/plant (6.68 g./ plant) was resulted in micro-elements at $90 \mathrm{ppm}$. followed by $5.44 \mathrm{~g} . /$ plant with micro-elements at $180 \mathrm{ppm}$., while the least

Table 8. Yield of dry sepals/ plant (g.) of Hibiscus sabdariffa, L. plant 
as affected by planting distances and some micro-elements, in 2006 and 2007 seasons.

\begin{tabular}{|c|c|c|c|c|c|c|c|c|}
\hline \multirow{2}{*}{$\begin{array}{l}\text { Micro-elements } \\
\text { concentrations } \\
(\mathrm{Fe}+\mathrm{Mn}+\mathrm{Zn}) \mathbf{p p m} .\end{array}$} & \multicolumn{8}{|c|}{ Planting distances (cm.) } \\
\hline & 40 & 60 & 80 & Mean & 40 & 60 & 80 & Mean \\
\hline & \multicolumn{4}{|c|}{2006} & \multicolumn{4}{|c|}{2007} \\
\hline Zero (control) & 3.25 & 4.83 & 5.13 & 4.40 & 7.60 & 10.38 & 7.12 & 8.37 \\
\hline 90 & 3.66 & 8.05 & 8.32 & 6.68 & 11.49 & 19.92 & 27.16 & 19.52 \\
\hline 180 & 5.38 & 5.29 & 5.65 & 5.44 & 13.63 & 17.84 & 18.96 & 16.81 \\
\hline Mean & 4.10 & 6.06 & 6.37 & & 10.91 & 16.05 & 17.75 & \\
\hline \multicolumn{3}{|c|}{ L.S.D at 0.05 for: Planting distances } & & $=1.18$ & & & & $=4.64$ \\
\hline \multicolumn{3}{|c|}{ : Micro-elements } & & $=1.38$ & & & & $=2.76$ \\
\hline \multicolumn{3}{|c|}{ : Interaction } & & $=2.39$ & & & & $=4.79$ \\
\hline
\end{tabular}

yield of dry sepals/plant (4.40 g./ plant) was obtained with zero microelements (control). In the second season, the yield of dry sepals/plant was higher than in the first one. The yields of dry sepals/plant $(8.37,19.52$ and $16.81 \mathrm{~g} . /$ plant) were produced from micro-elements at zero, 90 or $180 \mathrm{ppm}$., respectively.

Regarding planting spaces, it was observed that the yield of dry sepals/plant increased by increasing the distance between the plants. In the first season, the yields of dry sepals/ plant $(4.10,6.06$ and 6.37 g./ plant) were obtained with planting distances at 40,60 or $80 \mathrm{~cm}$., respectively, whereas, in the second season, the yields of dry sepals/plant (10.91, 16.05 and 17.75 g./plant) were produced with planting spaces at 40,60 or $80 \mathrm{~cm}$., respectively.

Concerning to the interaction between micro-elements and planting distances, it was clear that the interaction had a significant effect on yield of dry sepals/ plant. The highest yields of dry sepals/plant (8.32 and 27.16 g./ plant) were obtained from the interaction between micro-elements at $90 \mathrm{ppm}$. and planting distances at $80 \mathrm{~cm}$. in the first and second seasons, respectively. It was clear that the interaction between the micro-elements at 90 or $180 \mathrm{ppm}$. and different planting spaces increased yield of dry sepals/plant as compared with the interaction between the micro-elements at zero ppm. and different planting distances. These results of yield of fresh and dry sepals/plant were in agreement with those obtained by Hanafy et al. (2009 a) on Rosmarinus officinalis, reported that, cultivation at $80 \mathrm{~cm}$. between the plants in the row increased fresh and dry weights of herb as well as leaves/plant.

\section{9- Yield of dry seeds/plant (g.):}

As shown in Table (9) it can be observed that yield of dry seeds/plant increased significantly with micro-elements at 90 or $180 \mathrm{ppm}$. as compared Table 9. Yield of dry seeds/ plant (g.) of Hibiscus sabdariffa, L. plant 
as affected by planting distances and some micro-elements, in 2006 and 2007 seasons.

\begin{tabular}{|c|c|c|c|c|c|c|c|c|}
\hline \multirow{3}{*}{$\begin{array}{l}\text { Micro-elements } \\
\text { concentrations } \\
(\mathbf{F e}+\mathbf{M n}+\mathrm{Zn}) \text { ppm. }\end{array}$} & \multicolumn{8}{|c|}{ Planting distances (cm.) } \\
\hline & 40 & 60 & 80 & Mean & 40 & 60 & 80 & Mean \\
\hline & \multicolumn{4}{|c|}{2006} & \multicolumn{4}{|c|}{2007} \\
\hline Zero (control) & 10.20 & 12.24 & 14.50 & 12.31 & 14.25 & 30.81 & 21.16 & 22.07 \\
\hline 90 & 11.44 & 23.22 & 23.67 & 19.44 & 22.26 & 52.78 & 72.43 & 49.16 \\
\hline 180 & 17.45 & 13.11 & 19.89 & 16.82 & 35.23 & 57.89 & 79.44 & $\mathbf{5 7 . 5 2}$ \\
\hline Mean & 13.03 & 16.19 & 19.35 & & 23.91 & 47.16 & 57.68 & \\
\hline \multicolumn{4}{|c|}{ L.S.D at 0.05 for: Planting distances } & $=$ N.S. & & & & $=13.40$ \\
\hline \multicolumn{4}{|c|}{ : Micro-elements } & $=3.54$ & & & & $=5.90$ \\
\hline \multicolumn{4}{|c|}{ L.S.D at 0.05 for: Interaction } & $=6.14$ & & & & $=10.22$ \\
\hline
\end{tabular}

with the control treatment in the two seasons. In the first season, the yields of dry seeds/plant (12.31, 19.44 and 16.82 g./ plant) were obtained with micro-elements at zero (control), 90 or $180 \mathrm{ppm}$., respectively, while in the second season, the yields of dry seeds/plant $(22.07,49.16$ and 57.52 g./ plant) were resulted in micro-elements at zero, 90 or $180 \mathrm{ppm}$., respectively. Regarding planting distances, it was clear that, the yield of dry seeds/plant gradually increased as the distance between the plants increased.

In the first season, the yield of dry sepals/ plant (13.03, 16.19 and 19.35 g./ plant) was obtained with planting spaces at 40,60 or $80 \mathrm{~cm}$., respectively, while in the second season, the yield of dry seeds/plant (23.91, 47.16 and 57.68 g./ plant) was produced with planting spaces at 40,60 or $80 \mathrm{~cm}$., respectively.

The interaction between micro-elements at 90 or $180 \mathrm{ppm}$. and planting distances had a clear effect on increasing the yield of dry seeds/plant as compared with the interaction between micro-elements at zero and all planting spaces in the two seasons. In the first season, the highest yield of dry seeds/ plant (23.67 g./ plant) was produced from the interaction between micro-elements at $90 \mathrm{ppm}$. and planting spaces at $80 \mathrm{~cm}$., whereas, in the second season, the highest yield of dry seeds/ plant (79.44 g./ plant) was produced with the interaction between microelements at $180 \mathrm{ppm}$. and planting distance at $80 \mathrm{~cm}$.

These results were in harmony with those obtained by Khattab (1997) who stated that the seed yield of Hibiscus sabdariffa significantly increased with increasing $\mathrm{Mg}, \mathrm{Mn}, \mathrm{Cu}, \mathrm{Zn}, \mathrm{B}$, Mo and Co application.

10- Chlorophyll A content (mg/g. F.W.):

As shown in Table (10) it can be observed that chlorophyll A content increased significantly with micro-elements at 90 or $180 \mathrm{ppm}$. as compared with the control treatment in the two seasons.

Table 10. Chlorophyll A content (mg/ g. F.W.) in fresh leaves of 
Hibiscus sabdariffa, L. plant as affected by planting distances and some micro-elements, in 2006 and 2007 seasons.

\begin{tabular}{|c|c|c|c|c|c|c|c|c|}
\hline \multirow{2}{*}{$\begin{array}{l}\text { Micro-elements } \\
\text { concentrations } \\
(\mathrm{Fe}+\mathrm{Mn}+\mathrm{Zn}) \mathrm{ppm} .\end{array}$} & \multicolumn{8}{|c|}{ Planting distances $(\mathbf{c m})}$. \\
\hline & 40 & 60 & 80 & Mean & 40 & 60 & 80 & Mean \\
\hline & \multicolumn{4}{|c|}{2006} & \multicolumn{4}{|c|}{2007} \\
\hline Zero (control) & 0.570 & 0.603 & 0.640 & 0.604 & 0.660 & 0.693 & 0.747 & 0.700 \\
\hline 90 & 0.720 & 0.760 & 0.813 & 0.764 & 0.763 & 0.807 & 0.873 & 0.814 \\
\hline 180 & 0.867 & 0.973 & 1.263 & 1.034 & 0.927 & 1.040 & 1.463 & 1.143 \\
\hline Mean & 0.719 & 0.779 & 0.900 & & 0.783 & 0.847 & 1.028 & \\
\hline \multicolumn{4}{|c|}{ L.S.D at 0.05 for: Planting distances } & $=0.013$ & & & & $=0.072$ \\
\hline \multicolumn{3}{|c|}{ : Micro-elements } & & $=0.032$ & & & & $=0.046$ \\
\hline \multicolumn{3}{|c|}{ : Interaction } & & $=0.056$ & & & & $=0.080$ \\
\hline
\end{tabular}

There are gradually increasing in chlorophyll $\mathrm{A}$ as the micro-elements levels increased. In the first season, the chlorophyll A content $(0.604,0.764$ and $1.034 \mathrm{mg} /$ g. F.W.) was obtained with micro-elements at zero, 90 or 180 ppm., respectively, whereas in the second season, the chlorophyll A content $(0.700,0.814$ and $1.143 \mathrm{mg} / \mathrm{g}$. F.W.) were produced with micro-elements at zero, 90 or $180 \mathrm{ppm}$. respectively. Concerning to planting distances, it was clear that, the chlorophyll A content increased as planting spaces increased. There were significant differences between wider space $(80 \mathrm{~cm}$.) and the other planting spaces $(40$ or $60 \mathrm{~cm}$.) in the two seasons.

In the first season, the chlorophyll A content $(0.719,0.779$ and 0.900 $\mathrm{mg} /$ g. F.W.) was obtained with planting distances at 40, 60 or $80 \mathrm{~cm}$., respectively, whereas in the second season, the chlorophyll A content $(0.783$, 0.847 and $1.028 \mathrm{mg} / \mathrm{g}$. F.W.) was resulted in planting spaces at 40,60 or 80 cm., respectively.

The interaction between micro-elements at 90 or $180 \mathrm{ppm}$. and the planting distances had a clear effect on increasing the chlorophyll A content as compared with the interaction between micro-elements at zero and all planting spaces in the two seasons. The highest chlorophyll A contents (1.263 and $1.463 \mathrm{mg} / \mathrm{g}$. F.W.) were produced from the interaction between microelements at $180 \mathrm{ppm}$. and planting space at $80 \mathrm{~cm}$. in the first and second seasons, respectively.

\section{1- Chlorophyll B content (mg/ g. F.W.):}

As shown in Table (11) it can be observed that increasing microelements levels in both seasons increased steadily chlorophyll B content.

In the first season, the chlorophyll B content $(0.392,0.491$ and $700 \mathrm{mg} /$

Table 11. Chlorophyll B content (mg/ g. F.W.) in fresh leaves of 
Hibiscus sabdariffa, L. plant as affected by planting distances and some micro-elements, in 2006 and 2007 seasons.

\begin{tabular}{cccccccccc}
\hline $\begin{array}{l}\text { Micro-elements } \\
\text { concentrations } \\
\text { (Fe+Mn+Zn) ppm. }\end{array}$ & $\mathbf{4 0}$ & $\mathbf{6 0}$ & $\mathbf{8 0}$ & Mean & $\mathbf{4 0}$ & $\mathbf{6 0}$ & $\mathbf{8 0}$ & Mean \\
\cline { 2 - 9 } & \multicolumn{9}{c}{$\mathbf{2 0 0 6}$} \\
\cline { 2 - 9 } Zero (control) & 0.323 & 0.377 & 0.477 & $\mathbf{0 . 3 9 2}$ & 0.377 & 0.473 & 0.580 & $\mathbf{0 . 4 7 7}$ \\
$\mathbf{9 0}$ & 0.423 & 0.473 & 0.577 & $\mathbf{0 . 4 9 1}$ & 0.460 & 0.583 & 0.693 & $\mathbf{0 . 5 7 9}$ \\
$\mathbf{1 8 0}$ & 0.573 & 0.690 & 0.853 & $\mathbf{0 . 7 0 0}$ & 0.633 & 0.767 & 0.933 & $\mathbf{0 . 7 7 8}$ \\
\hline \multicolumn{1}{c}{ Mean } & $\mathbf{0 . 4 4 0}$ & $\mathbf{0 . 5 1 3}$ & $\mathbf{0 . 6 3 6}$ & & $\mathbf{0 . 4 9 0}$ & $\mathbf{0 . 6 0 8}$ & $\mathbf{0 . 7 3 0}$ & \\
\hline L.S.D at 0.05 for: Planting distances & & $=0.040$ & & & & $=0.013$ \\
& : Micro-elements & & $=0.029$ & & & & $=0.031$ \\
& : Interaction & & $=0.057$ & & & & $=0.055$ \\
\hline
\end{tabular}

g. F.W.) was resulted in micro-elements at zero, 90 or $180 \mathrm{ppm}$. respectively, with significant differences between each value and other. In the second season the same trend was observed which the chlorophyll B content $(0.477,0.579$ and $0.778 \mathrm{mg} / \mathrm{g}$. F.W.) was obtained from micro-elements at zero, 90 or $180 \mathrm{ppm}$., respectively, with significant differences between the values. Regarding planting distances, it was clear that, increasing the distance between the plants led to an increment in chlorophyll B content. In the first season, the chlorophyll B content $(0.440,0.513$ and $0.636 \mathrm{mg} / \mathrm{g}$. F.W.) was resulted in planting spaces at 40,60 or $80 \mathrm{~cm}$, respectively, with significant differences between the values. The same trend was observed in the second one which chlorophyll $\mathrm{B}$ contents $(0.490,0.608$ and $0.730 \mathrm{mg} / \mathrm{g}$. F.W.) were obtained from the planting distances at 40, 60 and $80 \mathrm{~cm}$., respectively, with significant differences between the values.

The interaction between micro-elements at 90 or $180 \mathrm{ppm}$. and the planting distances had a clear effect on increasing chlorophyll B content as compared with the interaction between micro-elements at zero and all planting distances in the two seasons. The highest chlorophyll B contents $(0.853$ and $0.933 \mathrm{mg} / \mathrm{g}$. F.W.) were obtained with the interaction between micro-elements at $180 \mathrm{ppm}$. and planting space at $80 \mathrm{~cm}$. in the first and second seasons, respectively.

\section{2- Carotenoids content (mg/g. F.W.):}

Data in Table (12) showed that increasing the micro-elements levels led to an increment in carotenoids content, with significant differences were observed between $180 \mathrm{ppm}$. treatment and the two other treatments of the micro-elements in both seasons.

In the first season, the carotenoids content $(0.303,0.429$ and 0.648

Table (12): Carotenoids content (mg/ g. F.W.) in fresh leaves of


Hibiscus sabdariffa, L. plant as affected by planting distances and some micro-elements, in 2006 and 2007 seasons.

\begin{tabular}{|c|c|c|c|c|c|c|c|c|}
\hline \multirow{3}{*}{$\begin{array}{l}\text { Micro-elements } \\
\text { concentrations } \\
(\mathrm{Fe}+\mathrm{Mn}+\mathrm{Zn}) \mathrm{ppm} .\end{array}$} & \multicolumn{8}{|c|}{ Planting distances $(\mathrm{cm})}$. \\
\hline & 40 & 60 & 80 & Mean & 40 & 60 & 80 & Mean \\
\hline & \multicolumn{4}{|c|}{2006} & \multicolumn{4}{|c|}{2007} \\
\hline Zero (control) & 0.263 & 0.297 & 0.350 & 0.303 & 0.320 & 0.373 & 0.413 & 0.369 \\
\hline 90 & 0.327 & 0.417 & 0.543 & 0.429 & 0.353 & 0.383 & 0.450 & 0.390 \\
\hline 180 & 0.533 & 0.627 & 0.783 & 0.648 & 0.550 & 0.650 & 0.800 & 0.670 \\
\hline Mean & 0.374 & 0.447 & 0.559 & & 0.408 & 0.460 & 0.554 & \\
\hline \multicolumn{4}{|c|}{ L.S.D at 0.05 for: Planting distances } & $=0.041$ & & & & $=0.013$ \\
\hline \multicolumn{4}{|c|}{ : Micro-elements } & $=0.032$ & & & & $=0.029$ \\
\hline \multicolumn{4}{|c|}{ : Interaction } & $=0.060$ & & & & $=0.056$ \\
\hline
\end{tabular}

mg/ g. F.W.) was obtained from micro-elements at zero, 90 or 180 ppm., respectively.

In the second season, similar trend was observed which the carotenoids content $(0.369,0.390$ and $0.670 \mathrm{mg} / \mathrm{g}$. F.W. $)$ was resulted in micro-elements at zero, 90 or $180 \mathrm{ppm}$, respectively. Concerning to planting spaces, it was clear that the increasing in planting distances, in both seasons, increased steadily carotenoids content, with significant differences were found between each value and other.

In the first season, the carotenoids content $(0.374,0.447$ and $0.559 \mathrm{mg} /$ g. F.W.) were resulted in planting spaces at 40,60 or $80 \mathrm{~cm}$., respectively. Whereas in the second season, the carotenoids content $(0.408,0.460$ and 0.554 $\mathrm{mg} / \mathrm{g}$. F.W.) were obtained with planting distances at 40,60 or $80 \mathrm{~cm}$., respectively. The interaction between micro-elements at 90 or $180 \mathrm{ppm}$. and planting spaces had a clear effect on increasing carotenoids content as compared with the interaction between micro-elements at zero and all planting distances in two seasons. The highest carotenoids contents $(0.783$ and $0.800 \mathrm{mg} / \mathrm{g}$. F.W. were resulted in the interaction between micro-elements at $180 \mathrm{ppm}$. and planting distance at $80 \mathrm{~cm}$. in the first and second seasons, respectively.

These results of chlorophyll A, B and carotenoids were in agreement with those obtained by Shoala (2000) on Lavandula multifida, found that $10 \mathrm{~g}$. NPK/plant with $25 \mathrm{ppm}$. Zn increased total chlorophylls, while with $50 \mathrm{ppm}$. Zn led to an increase in chlorophyll (b) and carotenoids content.

\section{3- Total carbohydrates percentage:}

Data shown in Table (13) revealed that total carbohydrates content in leaves of roselle increased steadily, in both seasons as the micro-elements levels increased, with significant differences were found between each value and other. Table 13. Total carbohydrates percentage in dry leaves of Hibiscus 
sabdariffa, L. plant as affected by planting distances and some micro-elements, in 2006 and 2007 seasons.

\begin{tabular}{|c|c|c|c|c|c|c|c|c|}
\hline \multirow{2}{*}{$\begin{array}{l}\text { Micro-elements } \\
\text { concentrations } \\
(\mathrm{Fe}+\mathrm{Mn}+\mathrm{Zn}) \mathrm{ppm} .\end{array}$} & \multicolumn{8}{|c|}{ Planting distances $(\mathbf{c m})}$. \\
\hline & 40 & 60 & 80 & Mean & 40 & 60 & 80 & Mean \\
\hline & \multicolumn{4}{|c|}{2006} & \multicolumn{4}{|c|}{2007} \\
\hline Zero (control) & 15.49 & 16.52 & 17.84 & 16.62 & 15.94 & 17.95 & 20.50 & 18.13 \\
\hline 90 & 16.81 & 18.09 & 20.48 & 18.46 & 18.91 & 21.29 & 23.98 & 21.39 \\
\hline 180 & 20.50 & 22.53 & 26.26 & 23.10 & 22.10 & 24.04 & 28.12 & 24.75 \\
\hline Mean & 17.60 & 19.05 & 21.53 & & 18.98 & 21.09 & 24.20 & \\
\hline \multicolumn{4}{|c|}{ L.S.D at 0.05 for: Planting distances } & $=0.54$ & & & & $=1.07$ \\
\hline \multicolumn{4}{|c|}{ : Micro-elements } & $=0.61$ & & & & $=0.93$ \\
\hline \multicolumn{4}{|c|}{ : Interaction } & $=1.05$ & & & & $=1.61$ \\
\hline
\end{tabular}

In the first season, total carbohydrates percentages $(16.62,18.46$ and $23.10 \%$ ) were obtained with micro-elemnts at zero, 90 and $180 \mathrm{ppm}$., respectively, while in the second season, the total carbohydrates percentage $(18.13,21.39$ and $24.75 \%)$ were produced with micro-elements at zero, 90 or 180 ppm., respectively. Regarding planting distances, it was clear that total carbohydrates percentage increased steadily, in both seasons as the distance between the plants increased.

The greatest total carbohydrates contents (21.53 and 24.20\%) were determined in the plants grown at $80 \mathrm{~cm}$. in the first and second seasons respectively, while the least total carbohydrates percentages $(17.60$ and $18.98 \%)$ were found in the plants cultivated at $40 \mathrm{~cm}$. in the first and second seasons, respectively. Whereas the plants cultivated at 60 $\mathrm{cm}$. gave 19.05 and $21.09 \%$ in the first and second seasons, respectively. There are significant differences between the values in the first and second seasons as a result of planting distances, these increase in total carbohydrates content as the planting distances increased may be due to the increase in photosynthetic pigments content as already mentioned, as well as the more available water, sunlight and minerals, consequently more production of carbohydrates.

The interaction between micro-elements at 90 or $180 \mathrm{ppm}$. and planting spaces had a significant effect on increasing total carbohydrates percentage in the two seasons as compared with the interaction between micro-elements at zero and all planting distances. The highest total carbohydrates percentages (26.26 and $28.12 \%$ ) were obtained with the interaction between micro-elements at $180 \mathrm{ppm}$. and planting distance at $80 \mathrm{~cm}$. in the first and second seasons, respectively.

These results were in agreement with those obtained by Ali (2008) on Origanum syriacum, L. who reported that planting distance at $60 \mathrm{~cm}$. 
increased total carbohydrates. Also, Hanafy et al. (2009 b) on Rosmarinus officinalis, L. stated that supplying the plants with $\mathrm{Zn}$ at $50 \mathrm{ppm}$. or 25 ppm. increased total carbohydrates content.

\section{4- Anthocyanin content (mg/ g. D.W.):}

Data presented in Table (14) showed that anthocyanin content in the sepals of roselle plant was affected by micro-elements, planting distances and their interaction between them. The anthocyanin content increased steadily in both seasons as the micro-elements levels increased, with significant differences between the values in each season. In the first season, anthocyanin contents $(14.21,16.18$ and $19.90 \mathrm{mg} / \mathrm{g}$.$) were$ obtained with micro-elements at zero, 90 or $180 \mathrm{ppm}$., respectively, while in the second season, anthocyanin contents $(15.02,18.55$ and $21.15 \mathrm{mg} / \mathrm{g}$.) were produced with micro-elements at zero, 90 or $180 \mathrm{ppm}$., respectively.

Concerning to planting spaces, it was clear that anthocyanin content increased steadily in both seasons as the distance between the plants increased, with significant differences were found between the values in each season. In the first season, anthocyanin contents $(15.45,16.63$ and $18.21 \mathrm{mg} /$ g. D.W.) were produced with planting distances at 40, 60 or $80 \mathrm{~cm}$. respectively, while in the second season, the anthocyanin contents $(16.87$, 18.12 and $19.73 \mathrm{mg} / \mathrm{g}$. D.W.) were produced with planting spaces at 40,60 or $80 \mathrm{~cm}$., respectively. These increases in anthocyanin content as planting spaces increased may be due to the increase in carbohydrates content as already mentioned as well as the more available mater, sunlight and minerals, consequently more production of anthocyanin.

The interaction between micro-elements at 90 or $180 \mathrm{ppm}$. and planting spaces had a significant effect on increasing anthocyanin content in the two seasons as compared with the interaction between micro-elements at zero and all planting distances. The highest anthocyanin contents (21.79 and $23.17 \mathrm{mg} / \mathrm{g}$. D.W.) were obtained with the interaction between microelements at $180 \mathrm{ppm}$. and planting space at $80 \mathrm{~cm}$. in the first and second seasons, respectively. These results were in agreement with those obtained by El-Sherbeny et al. (2005) on Sideritis montana, stated that the $40 \mathrm{~cm}$. distance between plants improved the chemical constituents during the two growth stages.

\section{5- $\mathrm{pH}$ values in beverage of sepals:}

As shown in Table (15), it was clear that $\mathrm{pH}$ values in beverage of sepals increased significantly as the micro-elements concentrations increased Table 14. Anthocyanin content (mg/ g. D.W.) in dry sepals of Hibiscus 
sabdariffa, L. plant as affected by planting distances and some micro-elements, in 2006 and 2007 seasons.

\begin{tabular}{|c|c|c|c|c|c|c|c|c|}
\hline \multirow{3}{*}{$\begin{array}{l}\text { Micro-elements } \\
\text { concentrations } \\
(\mathrm{Fe}+\mathrm{Mn}+\mathrm{Zn}) \mathbf{p p m} .\end{array}$} & \multicolumn{8}{|c|}{ Planting distances (cm.) } \\
\hline & 40 & 60 & 80 & Mean & 40 & 60 & 80 & Mean \\
\hline & \multicolumn{4}{|c|}{2006} & \multicolumn{4}{|c|}{2007} \\
\hline Zero (control) & 13.49 & 14.25 & 14.90 & 14.21 & 14.10 & 14.76 & 16.20 & 15.02 \\
\hline 90 & 14.79 & 15.81 & 17.95 & 16.18 & 17.00 & 18.83 & 19.83 & 18.55 \\
\hline 180 & 18.08 & 19.84 & 21.79 & 19.90 & 19.52 & 20.76 & 23.17 & 21.15 \\
\hline Mean & 15.45 & 16.63 & 18.21 & & 16.87 & 18.12 & 19.73 & \\
\hline \multicolumn{4}{|c|}{ L.S.D at 0.05 for: Planting distances } & $=0.88$ & & & & $=0.45$ \\
\hline \multicolumn{3}{|c|}{ : Micro-elements } & & $=0.46$ & & & & $=0.62$ \\
\hline \multicolumn{3}{|c|}{ : Interaction } & & $=0.80$ & & & & $=1.07$ \\
\hline
\end{tabular}

Table 15. PH values in beverage of sepals of Hibiscus sabdariffa, $\mathbf{L}$. plant as affected by planting distances and some microelements, in 2006 and 2007 seasons.

\begin{tabular}{|c|c|c|c|c|c|c|c|c|}
\hline \multirow{3}{*}{$\begin{array}{l}\text { Micro-elements } \\
\text { concentrations } \\
(\mathrm{Fe}+\mathrm{Mn}+\mathrm{Zn}) \mathrm{ppm} .\end{array}$} & \multicolumn{8}{|c|}{ Planting distances (cm.) } \\
\hline & 40 & 60 & 80 & Mean & 40 & 60 & 80 & Mean \\
\hline & \multicolumn{4}{|c|}{2006} & \multicolumn{4}{|c|}{2007} \\
\hline Zero (control) & 1.823 & 1.917 & 1.950 & 1.897 & 1.913 & 1.940 & 1.970 & 1.941 \\
\hline 90 & 2.283 & 2.333 & 2.370 & 2.330 & 2.420 & 2.517 & 2.623 & 2.520 \\
\hline 180 & 2.360 & 2.380 & 2.473 & 2.404 & 2.517 & 2.627 & 2.763 & 2.636 \\
\hline Mean & 2.150 & 2.210 & 2.260 & & 2.283 & 2.361 & 2.452 & \\
\hline \multicolumn{3}{|c|}{ L.S.D at 0.05 for: Planting distances } & & $=0.072$ & & & & $=0.013$ \\
\hline \multicolumn{3}{|c|}{ L.S.D at 0.05 for: Micro-elements } & & $=0.032$ & & & & $=0.010$ \\
\hline \multicolumn{3}{|c|}{ L.S.D at 0.05 for: Interaction } & & $=0.056$ & & & & $=0.018$ \\
\hline
\end{tabular}

in the two seasons. In the first season, the $\mathrm{pH}$ values (1.897, 2.330 and 2.404) were produced with micro-elements at zero, 90 and 180 ppm., respectively, whereas in the second season, the $\mathrm{pH}$ values $(1.941,2.520$ and 2.636) were resulted in micro-elements at zero, 90 or 180 ppm., respectively. Regarding planting distances, it was clear that $\mathrm{pH}$ values in beverage of sepals increased significantly as the planting distance between the plants increased in the two seasons.

In the first season, the $\mathrm{pH}$ values were $2.150,2.210$ and 2.260 while in the second season, the $\mathrm{pH}$ values were $2.283,2.361$ and 2.452 at planting distances 40,60 and $80 \mathrm{~cm}$, respectively.

The interaction between micro-elements at 90 or $180 \mathrm{ppm}$. and planting spaces had a significant effect on increasing $\mathrm{pH}$ values in beverage of sepals in the two seasons as compared with the interaction between microelements at zero and all planting distances. The highest $\mathrm{pH}$ values $(2.473$ and 2.763) were resulted in the interaction between micro-elements at $180 \mathrm{ppm}$. 
and planting distance at $80 \mathrm{~cm}$. in the first and second seasons, respectively. These results were in agreement with those obtained by El-Sawi and Mohamed (2002) stated that application of micro nutrients ( $\mathrm{Zn}$ and $\mathrm{Mn}$ ) had significant positive effects, in most cases, on chemical composition of cumin plant.

\section{6- Total soluble solids \%:}

Data presented in Table (16) indicated that percentages of total soluble solids in fresh sepals increased significantly as a result of application of micro-elements at $90 \mathrm{ppm}$. as compared with micro-elements at zero and $180 \mathrm{ppm}$. in both seasons.

In the first season, the total soluble solids \% (3.603, 4.346 and $3.776 \%$ ) were obtained with micro-elements at zero, 90 or $180 \mathrm{ppm}$., respectively whereas the percentages of total soluble solids in the second season $(3.977,4.702$ and $4.150 \%)$ were resulted in micro-elements at zero, 90 or 180 ppm., respectively. Concerning to planting distances, it was clear that total soluble solids \% increased as the planting spaces between the plants increased in the two seasons. In the first seasons, percentages of total soluble solids $(3.589,3.646$ and $4.490 \%)$ were obtained with planting spaces at 40, 60 or $80 \mathrm{~cm}$., respectively, while in the second season, total soluble solids \% (3.694, 4.539 and $4.601 \%$ ) were resulted in planting distances at 40,60 or 80 cm., respectively.

The interaction between micro-element and different planting distances had a clear effect on increasing total soluble solids\% in juice of fresh sepals in the two seasons as compared with the interaction between the micro-elements at zero and all plantings spaces. In the first season the highest value of total soluble solids $(4.867 \%)$ was produced with the interaction between micro-elements at $90 \mathrm{ppm}$. and planting space at $80 \mathrm{~cm}$., whereas the highest value in the second season $(4.950 \%)$ was resulted in the interaction between micro-elements at $90 \mathrm{ppm}$. and planting distance at $60 \mathrm{~cm}$.

These findings coincided with those of El-Sawi and Mohamed (2002) stated that application of $\mathrm{Zn}$ and $\mathrm{Mn}$, had significant positive effects, in most cases, on chemical composition of cumin plant.

\section{7- Iron content (ppm.) in the leaves:}

Data shown in Table (17) revealed that iron content in leaves of roselle increased steadily, in both seasons as the micro-elements levels increased, with significant differences were found between each value and other in both seasons.

In the first season, iron contents (191.11, 263.89 and $322.00 \mathrm{ppm}$.

\section{Table 16. Total soluble solids \% in juice of calyces and epicalyces of}


Hibiscus sabdariffa, L. plant as affected by planting distances and some micro-elements, in 2006 and 2007 seasons.

\begin{tabular}{|c|c|c|c|c|c|c|c|c|}
\hline \multirow{2}{*}{$\begin{array}{l}\text { Micro-elements } \\
\text { concentrations } \\
(\mathrm{Fe}+\mathrm{Mn}+\mathrm{Zn}) \mathbf{p p m} \text {. }\end{array}$} & \multicolumn{8}{|c|}{ Planting distances (cm.) } \\
\hline & 40 & 60 & 80 & Mean & 40 & 60 & 80 & Mean \\
\hline & \multicolumn{4}{|c|}{2006} & \multicolumn{4}{|c|}{2007} \\
\hline Zero (control) & 3.340 & 3.337 & 4.133 & 3.603 & 3.327 & 4.333 & 4.270 & 3.977 \\
\hline 90 & 4.000 & 4.170 & 4.867 & 4.346 & 4.223 & 4.950 & 4.933 & 4.702 \\
\hline 180 & 3.427 & 3.430 & 4.470 & 3.776 & 3.533 & 4.333 & 4.600 & 4.150 \\
\hline Mean & 3.589 & 3.646 & 4.490 & & 3.694 & 4.539 & 4.601 & \\
\hline \multicolumn{3}{|c|}{ L.S.D at 0.05 for: Planting distances } & \multicolumn{3}{|c|}{$=0.796$} & & & $=0.194$ \\
\hline \multicolumn{3}{|c|}{ : Micro-elements } & & $=0.230$ & & & & $=0.126$ \\
\hline \multicolumn{3}{|c|}{ : Interaction } & & $=0.398$ & & & & $=0.218$ \\
\hline
\end{tabular}

Table 17. Iron content (ppm.) in dry leaves of Hibiscus sabdariffa, L. plant as affected by planting distances and some microelements, in 2006 and 2007 seasons.

\begin{tabular}{|c|c|c|c|c|c|c|c|c|}
\hline \multirow{3}{*}{$\begin{array}{l}\text { Micro-elements } \\
\text { concentrations } \\
(\mathrm{Fe}+\mathrm{Mn}+\mathrm{Zn}) \mathrm{ppm} \text {. }\end{array}$} & \multicolumn{8}{|c|}{ Planting distances $(\mathrm{cm})}$. \\
\hline & 40 & 60 & 80 & Mean & 40 & 60 & 80 & Mean \\
\hline & \multicolumn{4}{|c|}{2006} & \multicolumn{4}{|c|}{2007} \\
\hline Zero (control) & 165.00 & 185.00 & 223.33 & 191.11 & 185.00 & 192.67 & 209.67 & 195.78 \\
\hline 90 & 210.00 & 255.00 & 326.67 & 263.89 & 218.33 & 235.33 & 275.33 & 243.00 \\
\hline 180 & 282.67 & 310.00 & 373.33 & 322.00 & 314.67 & 360.00 & 380.00 & 351.56 \\
\hline Mean & 219.00 & 250.00 & 307.78 & & 239.33 & 262.67 & 288.33 & \\
\hline \multicolumn{4}{|c|}{ L.S.D at 0.05 for: Planting distances } & $=29.76$ & & & & $=6.58$ \\
\hline \multicolumn{4}{|c|}{ : Micro-elements } & $=4.92$ & & & & $=23.00$ \\
\hline \multicolumn{4}{|c|}{ : Interaction } & $=8.51$ & & & & $=39.83$ \\
\hline
\end{tabular}

were produced with spraying by micro-elements at zero, 90 and $180 \mathrm{ppm}$, respectively, whereas in the second season, iron contents (195.78, 243.00 and $351.56 \mathrm{ppm}$.) were obtained with foliar spray by micro-elements at zero, 90 or $180 \mathrm{ppm}$. respectively.

Regarding planting distances, it was clear that, iron content increased steadily in both seasons as the distance between the plants increased with significant differences were found between the values in each season. In the first season, iron contents $(219.00,250.00$ and $307.78 \mathrm{ppm}$.) were obtained with planting spaces at 40,60 or $80 \mathrm{~cm}$., respectively, whereas in the second season, iron contents $(239.33,262.67$ and $288.33 \mathrm{ppm}$.) were resulted in planting distances at 40,60 or $80 \mathrm{~cm}$., respectively.

The interaction between micro-elements at 90 or $180 \mathrm{ppm}$. and planting distances had a significant effect on increasing iron contents in the 
two seasons as compared with the interaction between micro-elements at zero and all planting spaces, the highest iron contents (373.33 and $380.00 \mathrm{ppm}$.) were obtained with the interaction between micro-elements at $180 \mathrm{ppm}$. and planting space at $80 \mathrm{~cm}$. in the first and second seasons, respectively.

\section{8-Manganese content (ppm.) in the leaves:}

As shown in Table (18) it was clear that, manganese contents increased significantly as the micro-elements levels increased in the two seasons. In the first season, manganese contents (67.67, 91.11 and 127.67 ppm.) were obtained with micro-elements at zero, 90 or $180 \mathrm{ppm}$., respectively, whereas in the second season, the manganese contents $(76.56$, 90.78 and $141.56 \mathrm{ppm}$.) were resulted in spraying the plants by microelements at the rates of zero, 90 or 180 ppm., respectively.

Table 18. Manganese content (ppm.) in dry leaves of Hibiscus sabdariffa, L. plant as affected by planting distances and some micro-elements, in 2006 and 2007 seasons.

\begin{tabular}{|c|c|c|c|c|c|c|c|c|}
\hline \multirow{3}{*}{$\begin{array}{l}\text { Micro-elements } \\
\text { concentrations } \\
(\mathrm{Fe}+\mathrm{Mn}+\mathrm{Zn}) \mathrm{ppm} .\end{array}$} & \multicolumn{8}{|c|}{ Planting distances (cm.) } \\
\hline & 40 & 60 & 80 & Mean & 40 & 60 & 80 & Mean \\
\hline & \multicolumn{4}{|c|}{2006} & \multicolumn{4}{|c|}{2007} \\
\hline Zero (control) & 62.67 & 67.67 & 72.67 & 67.67 & 67.00 & 79.00 & 83.67 & 76.56 \\
\hline 90 & 82.67 & 92.33 & 98.33 & 91.11 & 80.33 & 88.67 & 103.33 & 90.78 \\
\hline 180 & 110.00 & 127.67 & 145.33 & 127.67 & 120.00 & 145.00 & 159.67 & 141.56 \\
\hline Mean & 85.11 & 95.89 & 105.44 & & 89.00 & 104.22 & 115.56 & \\
\hline \multicolumn{4}{|c|}{ L.S.D at 0.05 for: Planting distances } & $=8.87$ & & & & $=5.00$ \\
\hline \multicolumn{4}{|c|}{ : Micro-elements } & $=3.05$ & & & & $=5.43$ \\
\hline \multicolumn{4}{|c|}{ : Interaction } & $=5.28$ & & & & $=9.40$ \\
\hline
\end{tabular}

Regarding, planting spaces, it was clear that manganese content increased significantly as the micro-elements levels increased in both seasons.

In the first season, manganese contents $(85.11,95.89$ and $105.44 \mathrm{ppm}$. were resulted in planting distances at 40,60 or $80 \mathrm{~cm}$., respectively, whereas in the second season the manganese contents $(89.00,104.22$ and $115.56 \mathrm{ppm}$.) were obtained with planting spaces at 40,60 or $80 \mathrm{~cm}$., respectively. The interaction between the micro-elements at 90 or $180 \mathrm{ppm}$. and planting spaces had a significant effect on increasing manganese content in the two seasons as compared with the interaction between micro-elements at zero ppm. and all planting spaces. The highest manganese contents (145.33 and $159.67 \mathrm{ppm}$.) were obtained with the interaction between micro-elements at $180 \mathrm{ppm}$. and planting distance at $80 \mathrm{~cm}$. in the first and second seasons, respectively.

\section{9- Zinc content (ppm.) in the leaves:}


Data presented in Table (19) indicated that zinc content increased significantly as the micro-elements levels increased in the both seasons. In the first season, zinc contents $(47.11,64.67$ and $92.45 \mathrm{ppm}$.) were obtained with micro-elements at the rates of zero, 90 and $180 \mathrm{ppm}$., respectively, whereas in the second season, zinc contents $(46.78,67.66$ and $94.44 \mathrm{ppm}$.) were obtained with spraying the plants by micro-elements at the rates of zero, 90 and $180 \mathrm{ppm}$., respectively. Concerning to planting distances it was clear that zinc content increased as planting distances between the plants increased in both seasons.

In the first season, zinc contents $(64.89,67.56$ and $71.78 \mathrm{ppm}$.) were obtained with planting spaces at 40,60 and $80 \mathrm{~cm}$., respectively, while in the second season zinc contents $(66.55,69.33$ and $73.00 \mathrm{ppm}$.) were resulted in planting distances at 40,60 and $80 \mathrm{~cm}$., respectively.

Table 19. Zinc content (ppm.) in dry leaves of Hibiscus sabdariffa, $\mathbf{L}$. plant as affected by planting distances and some microelements, in 2006 and 2007 seasons.

\begin{tabular}{|c|c|c|c|c|c|c|c|c|}
\hline \multirow{2}{*}{$\begin{array}{l}\text { Micro-elements } \\
\text { concentrations } \\
(\mathrm{Fe}+\mathrm{Mn}+\mathrm{Zn}) \mathrm{ppm} \text {. }\end{array}$} & \multicolumn{8}{|c|}{ Planting distances (cm.) } \\
\hline & 40 & 60 & 80 & Mean & 40 & 60 & 80 & Mean \\
\hline & \multicolumn{4}{|c|}{2006} & \multicolumn{4}{|c|}{2007} \\
\hline Zero (control) & 42.00 & 45.67 & 53.67 & 47.11 & 45.00 & 46.67 & 48.67 & 46.78 \\
\hline 90 & 62.00 & 64.33 & 67.67 & 64.67 & 63.33 & 66.33 & 73.33 & 67.66 \\
\hline 180 & 90.67 & 92.67 & 94.00 & 92.45 & 91.33 & 95.00 & 97.00 & 94.44 \\
\hline Mean & 64.89 & 67.56 & 71.78 & & 66.55 & 69.33 & 73.00 & \\
\hline \multicolumn{3}{|c|}{ L.S.D at 0.05 for: Planting distances $=$} & 3.96 & & & & & $=3.17$ \\
\hline \multicolumn{3}{|c|}{ : Micro-elements = } & 1.75 & & & & & $=2.25$ \\
\hline \multicolumn{2}{|c|}{ : Interaction } & $=$ & 3.03 & & & & & $=3.90$ \\
\hline
\end{tabular}

The interaction between the micro-elements at 90 or $180 \mathrm{ppm}$. and planting distances had a significant effect on increasing zinc content in the two seasons as compared with the interaction between micro-elements at zero ppm. and all planting distances. The highest zinc contents (94.00 and $97.00 \mathrm{ppm}$.) were obtained with the interaction between micro-elements at $180 \mathrm{ppm}$. and planting distance at $80 \mathrm{~cm}$. in the first and second seasons, respectively.

These results of iron, manganese and zinc contents were in agreement with those obtained by Hanafy et al. (2009 b) on Rosmarinus officinalis, reported that supplying the plants with $\mathrm{Zn}$ at $50 \mathrm{ppm}$. increased $\mathrm{Zn}, \mathrm{B}$ and Mo in the herb, compared to control plants.

Conclusively, the foliar spray with micro-elements $(\mathrm{Fe}+\mathrm{Mn}+\mathrm{Zn}$ together) at the rates of 90 or $180 \mathrm{ppm}$. increased all the recorded characters of the growth, yield and chemical constituents as compared with the control treatment. 
The highest values of all recorded parameters of the growth, yield and chemical constituents were obtained with the wider space between the plants (80 $\mathrm{cm}$.) followed by medium space $(60 \mathrm{~cm}$.) then narrow space $(40 \mathrm{~cm}$.). Opposite trend was found with plant height. The interaction between micro-elements at 90 or $180 \mathrm{ppm}$. and different planting distances had a clear effect on increasing all recorded characters. Most of the recorded characters of the growth, yield and chemical constituents in second season were higher than that in the first one, this may be attributed by environmental conditions in both seasons.

\section{REFERENCES}

Ali, M.Y.M. (2008): Effect of fertilization, irrigation and planting distances on the growth and production of Origanum syriacum, L. plant under Sinai conditions. Ph. D. Thesis, Faculty of Agriculture, Cairo University, Egypt.

Diab, M. A. (1968): The chemical composition of Hibiscus sabdariffa, L. M. Sc. Thesis, Faculty of Agriculture, Cairo University, Egypt.

El-Gendy, S.A.; A.M. Hosni; S.S. Ahmed and R.M. Sabri (2001): Sweet basil (Ocimum basilicum, L.) productivity under different organic fertilization and inter-plant spacing levels in a newly reclaimed land in Egypt. Annals of Agricultural Science, Cairo, 46(1):319:338.

El-Sawi, S.A.; M.A. Mohamed (2002): Cumin herb as a new source of essential oils and its response to foliar spray with some micro-elements. FoodChemistry, 77(1):75-80.

El-Sherbeny, S.E.; M.Y. Khalil N.Y. Naguib (2005): Influence of compost levels and suitable spacings on the productivity of Sideritis montana, L. plants recently cultivated under Egyptian conditions. Bull. Faculty of Agriculture, Cairo University, 56(2):373-392.

El-Shobaky, S.A. and Y.T. Abd El-Mageed (2001): Response of pea plants to foliar spray with some micro-Nutrients $(\mathrm{Fe}, \mathrm{Zn}, \mathrm{Mn})$ in the new reclaimed sandy soil. The $5^{\text {th }}$ Arabian Horticulture Conference, Ismailia, Egypt, March 24-28.

Fahmy, R. (1970): Different quantitative estimation of some organic compound in plant, $72-73$ (in Arabic).

Freed, R.S.; P. Einensmith; S. Gutez; D. Reicosky; V. W. Smail and P. Wolberg (1989): User's Guide to MSTAT-C Analysis of Agronomic Research Experiments Michigan State University, East Lansing. USA.

Hanafy, M.S.; G.F. Ahmed; A. El-Zehewy and A.H. Mohamed (2009 a): Effect of planting distances on the growth, yield, essential oil 
productivity and chemical composition of rosemary (Rosmarinus officinalis, L.) plant. J. Product and Dev., 14 (1):111-128.

Hanafy, M.S.; G.F. Ahmed; A. El-Zehewy and A.H. Mohamed (2009 b): Effect of foliar spray with zinc, boron and molybdenum on the growth, yield, essential oil productivity and chemical composition of rosemary (Rosmarinus officinalis, L.) plant. J. Product and Dev., 14 (1):63-86.

Herbert ,D.; P. J. Phlipps and R. E. Strange ( 1971) : Determination of total carbohydrate. Method in Microbiology, 58 : 209 - 344 .

Ibrahem, Z.T.Z. (2000): Effect of some culture practices on growth and chemical composition of some medicinal plants under conditions of Northern Sinai. Ph. D. Thesis, Faculty of Agriculture, Kafr El-Sheikh, Tanta Univeristy, Egypt.

Khattab, M.E. (1997): Growth and yield response of roselle new cultivars to foliar nutrient application. Bull. of N.R.C., Cairo, 22:(4) 473-494.

Saric, M.; R. Kastrari; R. Curic; T. C. Cupina and I. Geric (1976): Chlorophyll Determination. Univerzit et U Noveon Sadu. Praktikumiz Fiziologize Biljaka-Beograd, Haucna Anjiga, 215.

Shoala, A.T. (2000): Physiological studies on lavender plant. Ph. D. Thesis, Faculty of Agriculture, Cairo University, Egypt.

Steel, R.G.D.; J.H. Torrie and D.A. Dickey (1997): Principles and Procedures of Statistics. A biometrical approach. $3^{\text {rd }}$ ed. Mc. Graw-Hill, New York.
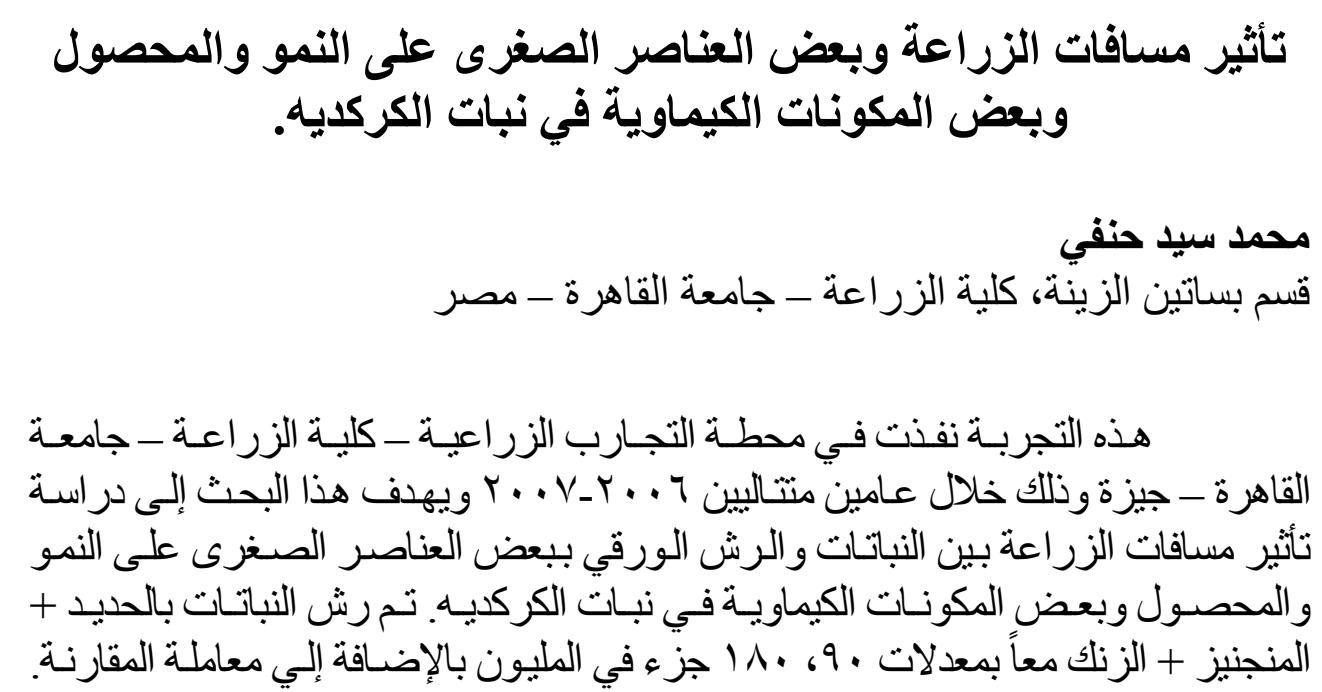
وكانت مسافات الزر اعة بين النباتات في هذه التجربة هي • ع، ، ج، ، 1 سم و المسافة بين الخطوط ثابتة وهي • آسم. و النتائج الرتحصل علئن عليها يمكن تلخيصها فيما يلي:

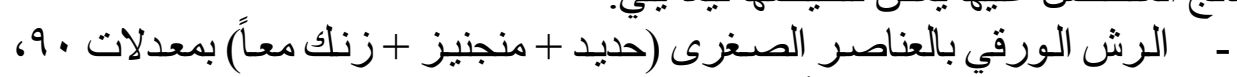

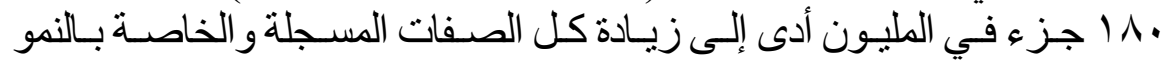

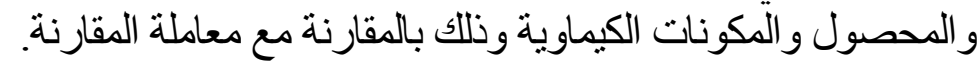

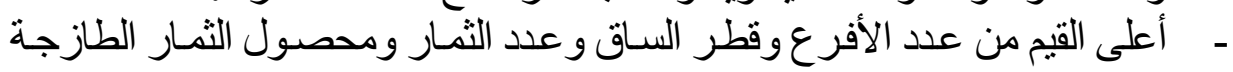

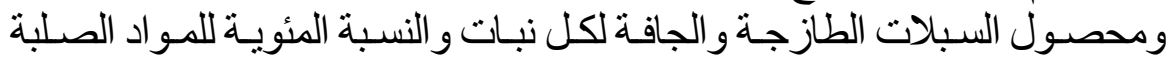

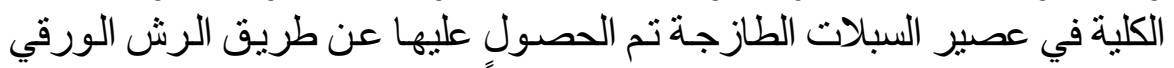

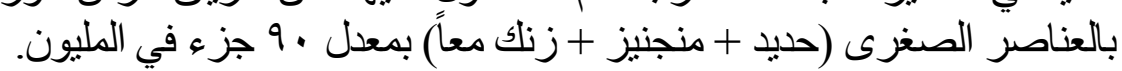

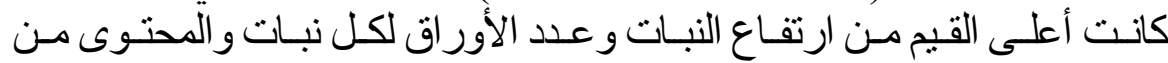

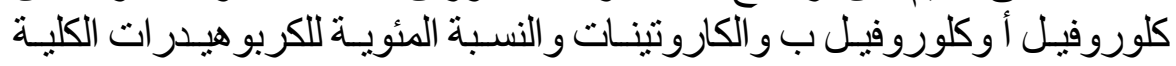

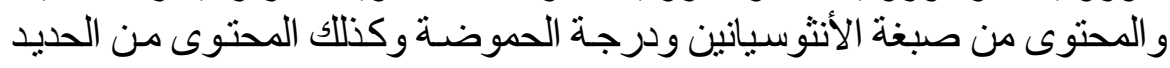

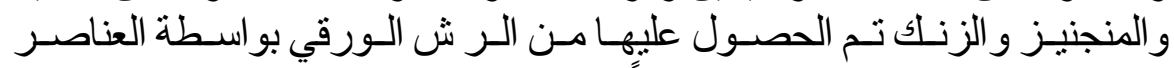

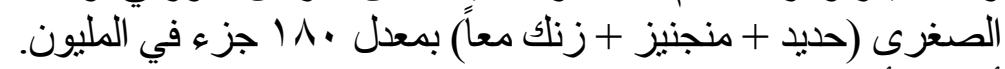

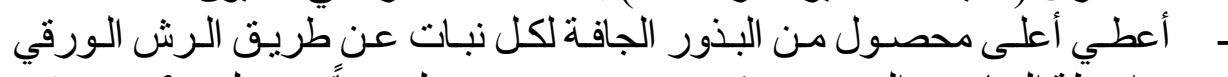

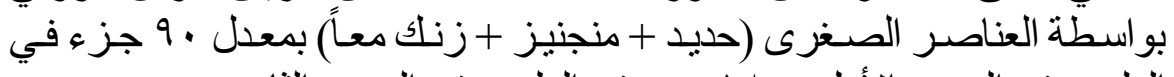

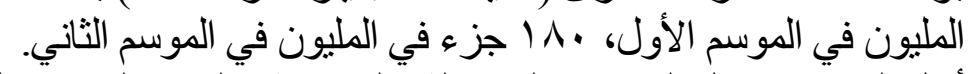

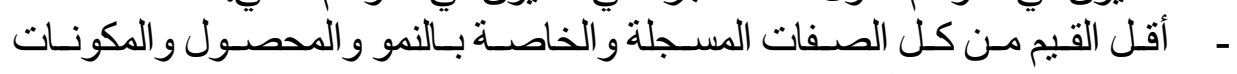
الكيماوية تم الحصول عليها من النباتات الغير معاملة بالعناصر الصغرى (معاملة الكية (المقارنة).

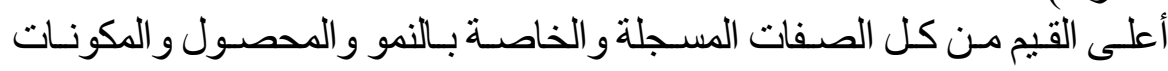

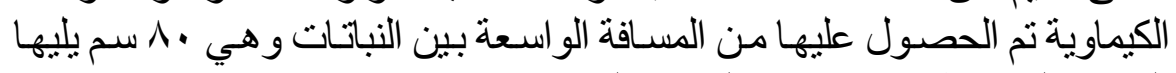

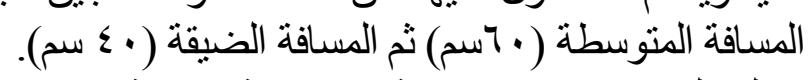

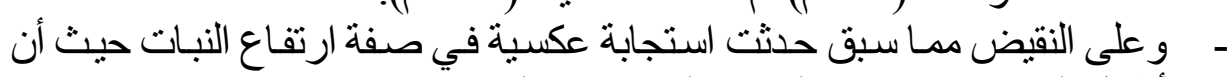

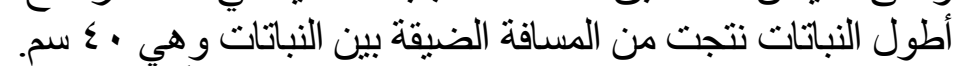

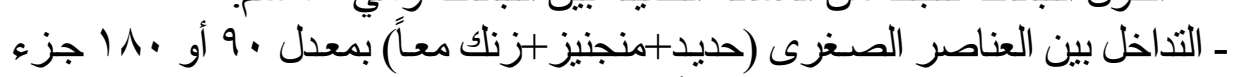

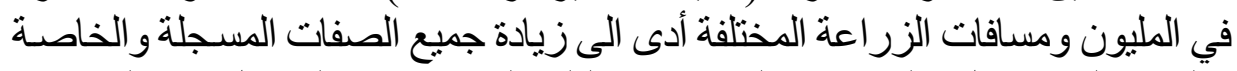

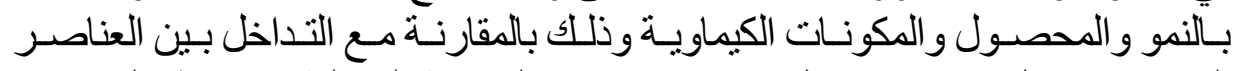
الصغرى بمعلل صفر (كترول) وجميع مسافات الزر اعة المختلفة في معظم الحالات. 